\title{
Incidence and determinants of high-sensitivity troponin and natriuretic peptides elevation at admission in hospitalized COVID-19 pneumonia patients
}

\author{
Luca Arcari ${ }^{1,2}$ - Michelangelo Luciani ${ }^{3} \cdot$ Luca Cacciotti $^{1,2} \cdot$ Maria Beatrice Musumeci $^{4,5} \cdot$ Valerio Spuntarelli $^{3,6}$. \\ Eleonora Pistella ${ }^{2,7}$. Dario Martolini ${ }^{2,7} \cdot$ Daniele Manzo $^{1,2} \cdot$ Mariateresa Pucci $^{2}$. Claudio Marone ${ }^{2,7}$. \\ Serena Melandri ${ }^{2,7} \cdot$ Gerardo Ansalone $^{1} \cdot$ Claudio Santini $^{2,7} \cdot$ Paolo Martelletti $^{3,6} \cdot$ Massimo Volpe $^{4,8}$. \\ Luciano De Biase ${ }^{5,9}$
}

Received: 25 June 2020 / Accepted: 5 September 2020 / Published online: 28 September 2020

c) Società Italiana di Medicina Interna (SIMI) 2020

\begin{abstract}
Background Myocardial involvement in the course of coronavirus disease 2019 (COVID-19) pneumonia has been reported, though not fully characterized yet. The aim of the present study is to undertake a joint evaluation of hs-Troponin and natriuretic peptides (NP) in patients hospitalized for COVID-19 pneumonia.

Methods In this multicenter observational study, we analyzed data from $n=111$ patients. Cardiac biomarkers subgroups were identified according to values beyond reference range.

Results Increased hs-Troponin and NP were found in 38 and 56\% of the cases, respectively. As compared to those with normal cardiac biomarkers, these patients were older, had higher prevalence of cardiovascular diseases (CVD) and had more severe COVID-19 pneumonia by higher CRP and D-dimer and lower PaO2/FIO2. Two-dimensional echocardiography performed in a subset of patients $(n=24)$ showed significantly reduced left ventricular ejection fraction in patients with elevated NP $(p=0.02)$, whereas right ventricular systolic function (tricuspid annular plane systolic excursion) was significantly reduced both in patients with high hs-Troponin and NP ( $p=0.022$ and $p=0.03$, respectively). Both hs-Troponin and NP were higher in patients with in-hospital mortality ( $p=0.001$ and $p=0.002$, respectively). On multivariable analysis, independent associations were found of hs-Troponin with age, PaO2/FIO2 and D-dimer $(B=0.419, p=0.001 ; B=-0.212, p=0.013$; and $B=0.179$, $p=0.037$, respectively) and of NP with age and previous $\operatorname{CVD}(B=0.480, p<0.001$; and $B=0.253, p=0.001$, respectively). Conclusions Myocardial involvement at admission is common in COVID-19 pneumonia. Independent associations of hsTroponin with markers of disease severity and of NP with underlying CVD might point toward existing different mechanisms leading to their elevation in this setting.
\end{abstract}

Keywords COVID-19 $\cdot$ Hs-troponin $\cdot$ Natriuretic peptide $\cdot \mathrm{D}$-dimer $\cdot \mathrm{PaO} 2 / \mathrm{FIO} 2$

\section{Introduction}

Coronavirus disease 2019 (COVID-19) is a respiratory infection caused by a novel type of betacoronavirus, 2019nCov, later renamed severe acute respiratory syndrome

Electronic supplementary material The online version of this article (https://doi.org/10.1007/s11739-020-02498-7) contains supplementary material, which is available to authorized users.

Luca Arcari

luca_arcari@outlook.it

Extended author information available on the last page of the article coronavirus 2 (SARS-CoV-2) [1], that emerged in China and later spread worldwide leading to a global pandemic. In some countries, this required the creation of dedicated multidisciplinary "COVID units" for the management of affected patients [2-4]. COVID-19 is a highly contagious infection [5], associated with a significant rate of severe interstitial pneumonia and related complications including respiratory failure, thrombosis, multiorgan failure and death [6]. Systemic implications include, among others, coagulopathy with increased D-dimer levels [7, 8], marker of more severe disease affecting prognosis [9]. Several reports also described the common occurrence of myocardial involvement in patients affected by COVID-19, as 
revealed by detection of increased levels of high-sensitivity troponin (hs-Troponin) [10,11] and natriuretic peptides (NP) [12] which both showed to have prognostic relevance [10, 13-15]. Reasons for myocardial injury in this setting span from cytokine or hypoxia-related injury to myocarditis and myocardial infarction [16-19]. A full understanding of mechanisms leading to myocardial involvement in the course of COVID-19 pneumonia might help gaining insights into disease pathogenesis and aid daily clinical management in these patients, in which downstream testing is usually complex and constitutes a risk for the safety of both patients and healthcare personnel [20]. Hence, the aim of the present study is to undertake a joint assessment of hs-Troponin and NP value at admission in a cohort of consecutively hospitalized COVID-19 pneumonia patients, in order to describe the incidence and the determinants of their rise.

\section{Methods}

This is a multicenter observational study on COVID-19 pneumonia patients $(n=118)$ consecutively admitted to dedicated medical units at Madre Giuseppina Vannini Hospital, Rome, Italy ( $n=39$, admission time between 1 and 30 April) and St. Andrea Hospital-Sapienza University of Rome, Italy ( $n=79$, admission time between 15 March and 30 April). Clinical care within these units, recently established in order to provide dedicated assistance to COVID-19 patients, was managed by full-time dedicated internal medicine or cardiology specialists.

Diagnosis of COVID-19 infection was confirmed before admission by means of nasopharyngeal swab and subsequent quantitative real-time reverse transcriptase polymerase chain reaction (qRT-PCR) [6], while pulmonary involvement was demonstrated in all patients by means of chest computed tomography. Symptoms at presentation and clinical history were assessed by the accepting physician. History of previous cardiovascular disease (CVD) was defined by the presence of either atrial fibrillation, coronary artery disease, heart failure or stroke. All patients underwent blood gas analysis, routine blood examination and 12-lead ECG within $24 \mathrm{~h}$ upon admission. Patients $(n=7)$ who did not have timely recorded blood gas analysis and assessment of either hs-Troponin or NP were excluded from the analysis. The final sample size consisted of $n=111$ patients of whom $n=103$ had hs-Troponin and $n=82$ had natriuretic peptide evaluation. No routine withdrawal of any previous treatment with cardiovascular drug was undertaken, while we recorded the presence of ongoing treatment with angiotensin-converting enzyme (ACE) inhibitor or angiotensin receptor blocker (ARB). Blood gas examination was performed with standard commercially available machines. Arterial oxygen concentration $(\mathrm{PaO} 2)$ was normalized to the fractional volume of the inspired oxygen to calculate the $\mathrm{PaO} 2 / \mathrm{FIO} 2$ ratio. Venous blood samples were analyzed by standard techniques within $2 \mathrm{~h}$ from collection. Hs-Troponin $\mathrm{T}$ (normal value $<14 \mathrm{pg} / \mathrm{ml}$ ) and $\mathrm{N}$-terminal-pro-natriuretic peptide (NT-pro-BNP) were evaluated at Madre Giuseppina Vannini Hospital. Hs-Troponin I (normal value $<35$ pg/ml) and B-type natriuretic peptide (BNP) were evaluated at St. Andrea Hospital. D-dimer results were reported as fibrinogen equivalent units [21]. In order to provide unified analysis of different NPs at our institutions, we referred to specific upper range for normality (URN) as suggested by guidelines (NT-pro-BNP: 300 pg/ml; BNP: 100 pg/ml) [22]. We then reported data from our population as factor of URN increase as described in [23]. Data regarding hs-Troponin, NP, D-dimer and C-reactive protein (CRP) were all $\log 10$ transformed to yield approximately normal distribution when performing analysis of relationships as well as multivariable analysis. Outcome data are updated at May 31, 2020.

All analysis was performed using SPSS software 25 (SPSS Inc., Chicago, IL). Data are presented as mean \pm standard deviation, counts (percentages) or median (interquartile range, IQR), as appropriate. Comparisons between groups were performed using Chi-squared test, Fisher's exact test, Student t-test for independent samples or Mann-Whitney U test as appropriate. Analysis of relationships was performed using bivariate correlation and providing corresponding Pearson's or Spearman correlation coefficients as appropriate. Log-transformed values for serum biomarkers (hs-Troponin, NP, D-dimer, CRP) were used. Multivariable linear regression was performed to investigate factors independently associated with hs-Troponin and $\mathrm{NP}$, and using age, hemoglobin, creatinine, history of previous CVD, $\mathrm{PaO} 2 / \mathrm{FIO} 2$ and CRP and D-dimer as independent variables. All tests were two-tailed, and $p$ value of $<0.05$ was considered statistically significant. All patients provided informed consent for the use of their record for research purpose, and the study complied with the content of the Declaration of Helsinki. This study received the approval from Sapienza University Ethic Committee no. CE_5773_2020.

\section{Results}

\section{Baseline characteristics}

Baseline clinical and demographic findings in $n=111$ patients included in the study are summarized in Table 1 . Mean age was $72 \pm 17$ years and $46 \%$ were male. Comorbidities were common in our population, more than half of the patients had known hypertension, approximately one-third had preexisting CVD, and $22 \%$ were taking an ACE inhibitor or ARB before hospital admission. Venous 
Table 1 Characteristics of study population overall and according to cardiac biomarkers levels at admission

\begin{tabular}{|c|c|c|c|c|c|c|c|}
\hline \multirow[t]{2}{*}{ Variable } & \multirow[t]{2}{*}{ Overall $(n=111)$} & \multicolumn{3}{|c|}{ Hs-Troponin $(n=103)$} & \multicolumn{3}{|c|}{ Natriuretic peptide $(n=82)$} \\
\hline & & $\begin{array}{l}\text { Hs-Tro- } \\
\text { ponin } \leq \text { URN } \\
(\mathrm{n}=64)\end{array}$ & $\begin{array}{l}\text { Hs-Troponin }>\text { URN } \\
(\mathrm{n}=39)\end{array}$ & $P$ & $\mathrm{NP} \leq \mathrm{URN}(n=36)$ & $\mathrm{NP}>\mathrm{URN}(n=46)$ & $\mathrm{P}$ \\
\hline Age & $72 \pm 17$ & $66 \pm 17$ & $79 \pm 13$ & $<0.001$ & $61 \pm 17$ & $81 \pm 9$ & $<0.001$ \\
\hline Sex (male) & $51(46 \%)$ & $28(44 \%)$ & $19(49 \%)$ & 0.623 & $21(58 \%)$ & $21(46 \%)$ & 0.254 \\
\hline \multicolumn{8}{|l|}{ Coexistent conditions } \\
\hline Hypertension & $62(56 \%)$ & $32(50 \%)$ & $26(67 \%)$ & 0.098 & $15(42 \%)$ & $31(67 \%)$ & 0.02 \\
\hline Dyslipidemia & $15(14 \%)$ & $8(12 \%)$ & $6(15 \%)$ & 0.679 & $2(6 \%)$ & $9(20 \%)$ & 0.065 \\
\hline Diabetes & $21(19 \%)$ & $12(19 \%)$ & $8(20 \%)$ & 0.826 & $6(17 \%)$ & $9(20 \%)$ & 0.736 \\
\hline Previous CVD & $35(31 \%)$ & $13(20 \%)$ & $18(46 \%)$ & 0.006 & $4(11 \%)$ & $26(56 \%)$ & $<0.001$ \\
\hline Atrial fibrillation & $21(19 \%)$ & $6(9 \%)$ & $12(31 \%)$ & 0.006 & $1(3 \%)$ & $17(37 \%)$ & $<0.001$ \\
\hline $\begin{array}{l}\text { Coronary artery } \\
\text { disease }\end{array}$ & $12(11 \%)$ & $5(8 \%)$ & $7(18 \%)$ & 0.120 & $0(0 \%)$ & $11(24 \%)$ & 0.002 \\
\hline Heart failure & $8(7 \%)$ & $1(2 \%)$ & $5(13 \%)$ & 0.028 & $0(0 \%)$ & $7(100 \%)$ & 0.016 \\
\hline Stroke & $8(7 \%)$ & $3(5 \%)$ & $4(10 \%)$ & 0.422 & $3(8 \%)$ & $5(11 \%)$ & $>0.99$ \\
\hline CKD & $7(6 \%)$ & $2(3 \%)$ & $5(13 \%)$ & 0.101 & $0(0 \%)$ & $6(13 \%)$ & 0.024 \\
\hline COPD & $26(23 \%)$ & $18(28 \%)$ & $6(15 \%)$ & 0.138 & $6(17 \%)$ & $10(22 \%)$ & 0.565 \\
\hline Cancer & $8(7 \%)$ & $6(9 \%)$ & $1(3 \%)$ & 0.249 & $1(3 \%)$ & $5(11 \%)$ & 0.223 \\
\hline Autoimmune disease & $6(5 \%)$ & $4(6 \%)$ & $2(5 \%)$ & $>0.99$ & $4(11 \%)$ & $2(4 \%)$ & 0.397 \\
\hline $\begin{array}{l}\text { ACE inhibitor/ARB } \\
\text { therapy }\end{array}$ & $24(22 \%)$ & $12(19 \%)$ & $9(23 \%)$ & 0.597 & $8(22 \%)$ & $13(28 \%)$ & 0.534 \\
\hline \multicolumn{8}{|l|}{ Laboratory tests } \\
\hline $\mathrm{Hb}(\mathrm{g} / \mathrm{dl})$ & $11.8 \pm 2$ & $12.1 \pm 2$ & $11.6 \pm 2$ & 0.181 & $12.7 \pm 2$ & $11.2 \pm 1.7$ & 0.002 \\
\hline WBC (per $\mu \mathrm{L})$ & $7839 \pm 4777$ & $8147 \pm 5430$ & $7880 \pm 3546$ & 0.786 & $6876 \pm 3187$ & $8132 \pm 6201$ & 0.274 \\
\hline Neutrophil (per $\mu \mathrm{L}$ ) & $4857 \pm 3034$ & $4597 \pm 2746$ & $5582 \pm 3412$ & 0.148 & $3705 \pm 1972$ & $4719 \pm 2909$ & 0.141 \\
\hline Lymphocyte (per $\mu \mathrm{L}$ ) & $1402 \pm 1196$ & $1575 \pm 1415$ & $1220 \pm 836$ & 0.192 & $1473 \pm 887$ & $990 \pm 550$ & 0.011 \\
\hline Creatinine $(\mathrm{mg} / \mathrm{dl})$ & $1.13 \pm 1$ & $0.96 \pm 0.9$ & $1.43 \pm 1.9$ & 0.025 & $0.78 \pm 0.2$ & $1.51 \pm 1.4$ & 0.002 \\
\hline $\operatorname{ALT}(\mathrm{U} / \mathrm{L})$ & $32 \pm 52$ & $26 \pm 13$ & $45 \pm 87$ & 0.098 & $25 \pm 15$ & $41 \pm 80$ & 0.238 \\
\hline AST (U/L) & $30 \pm 39$ & $26 \pm 18$ & $42 \pm 65$ & 0.083 & $24 \pm 12$ & $38 \pm 60$ & 0.294 \\
\hline $\mathrm{CRP}(\mathrm{mg} / \mathrm{dl})$ & $4.8(1.3,9)$ & $4(1.1,7.4)$ & $9(1.3,14.3)$ & 0.042 & $2.6(0.6,6.9)$ & $5.3(2.2,11.4)$ & 0.011 \\
\hline D-dimer (ng/ml FEU) & $566(293,1554)$ & $442(244,778)$ & $1269(560,2759)$ & $<0.001$ & $338(248,1058)$ & $990(463,2054)$ & 0.004 \\
\hline Hs-Troponin (pg/ml) & $17(5,47)$ & $6.8(4,15)$ & $60(35,94)$ & NA & $6.2(4,16)$ & $37.6(19,82)$ & $<0.001$ \\
\hline Hs-Troponin $>$ URN & $39 / 103(38 \%)$ & $0(0 \%)$ & $39(100 \%)$ & NA & $6(18 \%)$ & $27(64 \%)$ & $<0.001$ \\
\hline $\begin{array}{l}\text { Hs-Troponin } \\
\quad(>3 \times \text { URN })\end{array}$ & $17 / 103(16 \%)$ & $0(0 \%)$ & $17(43 \%)$ & NA & $0(0 \%)$ & $16(42 \%)$ & $<0.001$ \\
\hline $\mathrm{NP}($ factor $\times \mathrm{URN})$ & $1.35(0.35,3.56)$ & $0.7(0.1,1.8)$ & $3(1.3,15)$ & 0.003 & $0.3(0.1,0.6)$ & $3.3(1.8,15)$ & NA \\
\hline $\mathrm{NP}>\mathrm{URN}$ & $46 / 82(56 \%)$ & $15 / 42(36 \%)$ & $27 / 33(82 \%)$ & $<0.001$ & $0(0 \%)$ & $46(100 \%)$ & NA \\
\hline \multicolumn{8}{|l|}{ Blood gas analysis } \\
\hline $\mathrm{pH}$ & $7.44 \pm 0.08$ & $7.43 \pm 0.07$ & $7.46 \pm 0.08$ & 0.045 & $7.45 \pm 0.07$ & $7.44 \pm 0.08$ & 0.571 \\
\hline $\mathrm{pO} 2(\mathrm{mmHg})$ & $75 \pm 22$ & $75 \pm 20$ & $75 \pm 24$ & 0.856 & $74 \pm 19$ & $76 \pm 21$ & 0.630 \\
\hline $\mathrm{pCO} 2(\mathrm{mmHg})$ & $38 \pm 7$ & $39 \pm 6$ & $37 \pm 7$ & 0.108 & $39 \pm 6$ & $38 \pm 7$ & 0.375 \\
\hline $\mathrm{PaO} 2 / \mathrm{FIO} 2$ & $308 \pm 99$ & $325 \pm 97$ & $276 \pm 92$ & 0.012 & $342 \pm 91$ & $293 \pm 100$ & 0.024 \\
\hline \multicolumn{8}{|c|}{ Echocardiograpghic findings* } \\
\hline $\operatorname{LVEF}(\%)$ & $55(50,60)$ & $60(53,60)$ & $55(40,55)$ & 0.112 & $60(55,60)$ & $55(40,55)$ & 0.01 \\
\hline TAPSE (mm) & $21(19,23)$ & $23(22,24)$ & $20(18,22)$ & 0.022 & $22(20,24)$ & $19(17,22)$ & 0.03 \\
\hline \multicolumn{8}{|l|}{ In-hospital outcome } \\
\hline In-hospital death & $23(21 \%)$ & $7(11 \%)$ & $12(31 \%)$ & 0.012 & $5(14 \%)$ & $15(33 \%)$ & 0.05 \\
\hline
\end{tabular}

Bold values indicates $p<0.05$

$N P$ Natriuretic peptide, $U R N$ upper reference of normality, $C V D$ cardiovascular disease, $C K D$ chronic kidney disease, $C O P D$ chronic obstructive pulmonary disease, $A C E$ angiotensin-converting enzyme, $A R B$ angiotensin receptor blocker, $H b$ hemoglobin, $W B C$ white blood cells, $A S T$ aspartate transaminase, $A L T$ alanine transaminase, $C R P \mathrm{C}$-reactive protein, $F E U$ fibrinogen equivalent unit, $L V E F$ left ventricular ejection fraction, TAPSE tricuspid annular plane systolic excursion, $N A$ not applicable

*Available in 24 out of 111 patients 
blood samples analysis revealed increase of median CRP and D-dimer. We detected raised troponin (identified by value $>$ URN) in $38 \%$ of the cases, whereas in $16 \%$ of the patients the increase was beyond three times the respective URN. NP values were elevated in $56 \%$ of the cases. On blood gas analysis, mean $\mathrm{PaO} 2$ was $75 \pm 22 \mathrm{mmHg}$ and mean $\mathrm{PaO} 2 / \mathrm{FIO} 2308 \pm 99$. In-hospital mortality rate in our population was $21 \%(n=23)$.

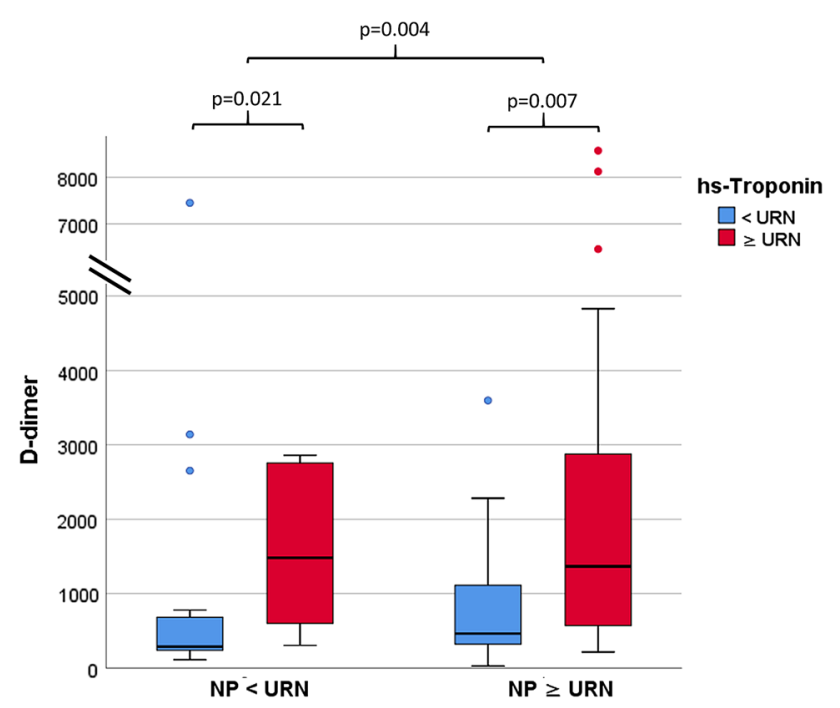

Fig. 1 Boxplot shows significantly higher D-dimer values in patients with hs-Troponin beyond URN, both in patients with normal $(p=0.021)$ and elevated $(p=0.007) \mathrm{NP}$

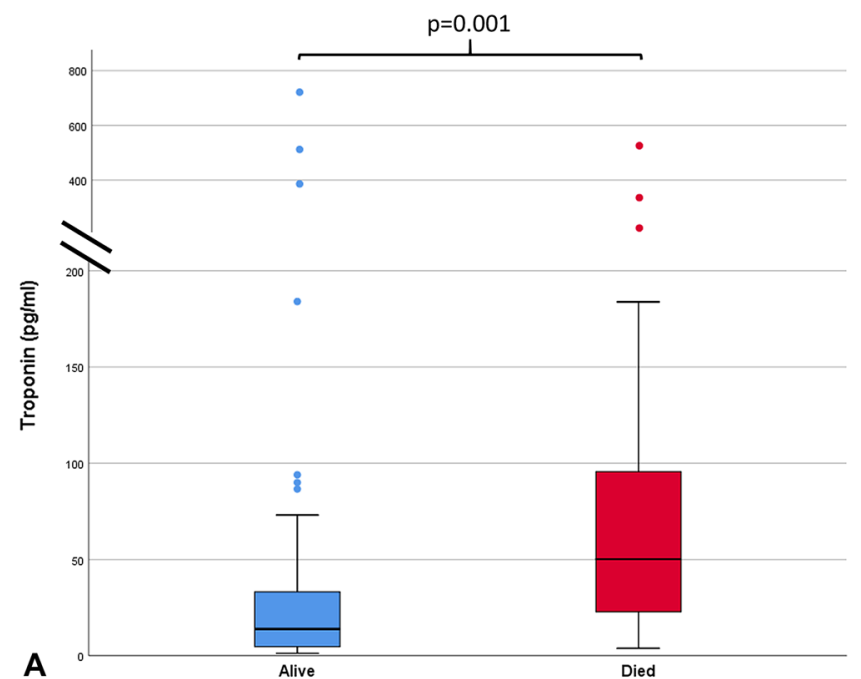

\section{Characteristics of population according to cardiac biomarkers}

On subgroups analysis, patients who had raised hs-Troponin at admission were older, with higher prevalence of previous CVD (46\% vs 20\%) and NP beyond URN (82\% vs 36\%), higher CRP $(9(1.3,14.3) \mathrm{mg} / \mathrm{dl}$ vs $4(1.1,7.4) \mathrm{mg} / \mathrm{dl})$ and creatinine $(1.43 \pm 1.9 \mathrm{mg} / \mathrm{dl}$ vs $0.96 \pm 0.9 \mathrm{mg} / \mathrm{dl})$ values, whereas they had lower $\mathrm{PaO} 2 / \mathrm{FIO} 2(276 \pm 92$ vs $325 \pm 97)$ as compared to those with normal hs-Troponin. Of note, D-dimer was significantly increased in patients with high hsTroponin at admission (1269 (560, 2759) ng/ml vs 442 (244, 778) $\mathrm{ng} / \mathrm{ml}$ ). These findings were similarly represented in patients with NP beyond cut-off levels. D-dimer was significantly elevated in patients with high hs-Troponin, irrespective of whether they had normal or high NP (Fig. 1). Rate of (ACE) inhibitor or ARB intake before hospital admission was similar between cardiac biomarkers subgroups. Both patients with hs-Troponin and NP beyond normal values experienced higher rate of in-hospital mortality (31\% vs $11 \%, p=0.012$, and $33 \%$ vs $14 \%, p=0.05$, respectively). In patients with worse in-hospital outcome, we detected higher levels of both hs-Troponin and NP ( $p=0.001$ and $p=0.002$, respectively, depicted in Fig. 2).

\section{Echocardiographic findings}

Transthoracic echocardiography was performed in 24 patients $(22 \%)$ within the overall population. Median left ventricular ejection fraction (LVEF) and tricuspid annular plane systolic excursion (TAPSE) were 55\% $(50,60)$ and $21 \mathrm{~mm}(19,23)$, respectively. LVEF was significantly lower in patients with elevated NP, but not in those with elevated

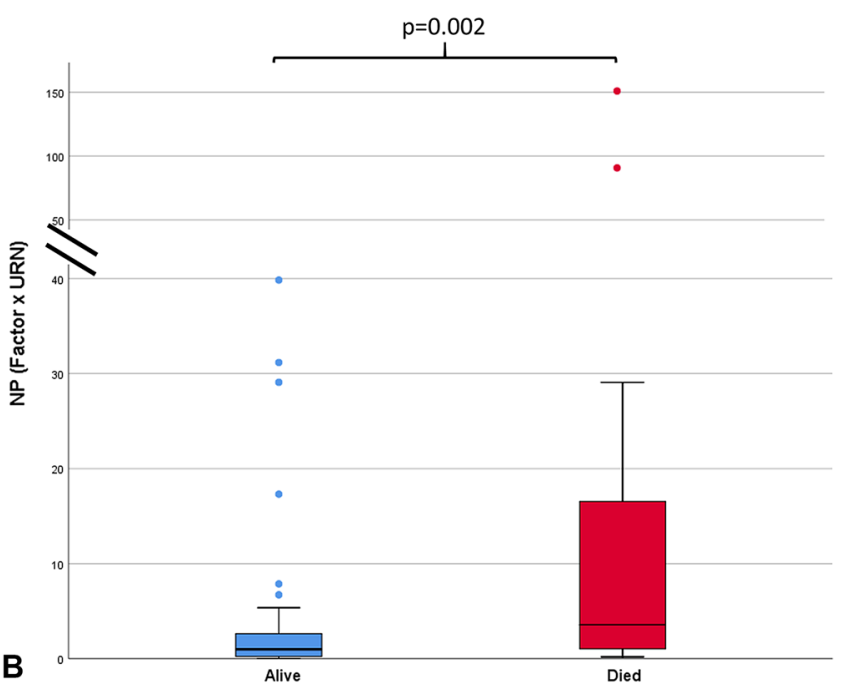

Fig. 2 Boxplots showing significantly higher cardiac biomarkers levels in patients with poor in-hospital outcome. Hs-Troponin (a) and NP (b) with $p=0.001$ and $p=0.002$, respectively 
hs-Troponin ( $p=0.02$ and $p=0.112$, respectively). TAPSE was significantly lower in both groups of elevated cardiac biomarkers (hs-Troponin: $20 \mathrm{~mm}(18,22)$ vs $23 \mathrm{~mm}(22,24)$, $p=0.022$; NP: $19 \mathrm{~mm}(17,22)$ vs $22 \mathrm{~mm}(20,24), p=0.03)$.

\section{Analysis of relationships}

Analysis of relationships results are summarized in Table 2. We observed a significant and close correlation between hsTroponin and NP values $(r=-0.730, p<0.001$; Supplementary Fig. 1). Both hs-Troponin and NP were associated with age $(r=0.484$ and $r=0.696$, respectively, both $p<0.001)$ and history of previous CVD $(r=0.332$ and $r=0.489$ with $p=0.001$ and $p<0.001$, respectively), as well as with hemoglobin and creatinine levels. Moreover, we detected significant associations between both cardiac biomarkers on one side and indexes of COVID-19 pneumonia severity on the other (depicted in Fig. 3). These relationships were significant for hs-Troponin (CRP: $r=0.396, p<0.001$; D-dimer: $r=0.366, p<0.001: \mathrm{PaO} 2 / \mathrm{FIO} 2: r=-0.411, p<0.001)$ as well as NP (CRP: $r=0.293, p=0.008$; D-dimer: $r=0.358$, $p=0.001: \mathrm{PaO} 2 / \mathrm{FIO} 2: r=-0.347, p=0.001)$.

On multivariable analysis (Table 3 ) including age, creatinine, hemoglobin, CRP, D-dimer and $\mathrm{PaO} 2 / \mathrm{FIO} 2$, we observed independent associations between hs-Troponin and age $(B=0.419, p=0.001), \mathrm{PaO} 2 / \mathrm{FIO} 2(B=-0.212$,

Table 2 Bivariate correlations of hs-Troponin and NP with patients' characteristics and laboratory results

\begin{tabular}{|c|c|c|c|c|}
\hline \multirow[t]{2}{*}{ Variable } & \multicolumn{2}{|c|}{ Troponin $(\log 10)$} & \multicolumn{2}{|c|}{$\begin{array}{l}\text { NP }(\log 10 \text { (factor } \\
\times \text { URN)) }\end{array}$} \\
\hline & $R$ & $P$ & $R$ & $P$ \\
\hline Age & 0.484 & $<0.001$ & 0.696 & $<0.001$ \\
\hline Sex (male) & 0.012 & 0.907 & -0.180 & 0.106 \\
\hline Previous CVD & 0.332 & 0.001 & 0.489 & $<0.001$ \\
\hline ACE inhibitor/ARB therapy & 0.021 & 0.833 & 0.156 & 0.162 \\
\hline Creatinine $(\mathrm{mg} / \mathrm{dl})$ & 0.288 & 0.003 & 0.244 & 0.027 \\
\hline $\mathrm{Hb}(\mathrm{g} / \mathrm{dl})$ & -0.213 & $\mathbf{0 . 0 3 1}$ & -0.412 & $<0.001$ \\
\hline CRP (Log10) & 0.396 & $<0.001$ & 0.293 & 0.008 \\
\hline D-dimer $(\log 10)$ & 0.366 & $<0.001$ & 0.358 & 0.001 \\
\hline Hs-Troponin $(\log 10)$ & NA & NA & 0.730 & $<0.001$ \\
\hline NP factor x URN $(\log 10)$ & 0.730 & $<0.001$ & NA & NA \\
\hline $\mathrm{pH}$ & 0.063 & 0.535 & -0.040 & 0.728 \\
\hline pO2 & 0.030 & 0.766 & -0.086 & 0.443 \\
\hline $\mathrm{pCO} 2$ & -0.059 & 0.560 & -0.049 & 0.667 \\
\hline $\mathrm{PaO} 2 / \mathrm{FIO} 2$ & -0.411 & $<0.001$ & -0.347 & 0.001 \\
\hline
\end{tabular}

Pearson's and Spearman (rho) coefficient, as appropriate for the type of the data; $p$ value $<0.05$ was considered significant. Bold values indicates $p<0.05$

$N P$ Natriuretic peptide, $C V D$ cardiovascular disease, $A C E$ angiotensin-converting enzyme, $A R B$ angiotensin receptor blocker, $H b$ hemoglobin, $C R P$ C-reactive protein, $N A$ not applicable $p=0.013)$ and D-dimer $(B=0.179, p=0.037)$, whereas NP remained associated with age $(B=0.480, p<0.001)$ and history of previous $\operatorname{CVD}(B=0.253, p=0.001)$.

\section{Discussion}

Results from our multicenter observational study highlight the common occurrence of myocardial involvement in patients with COVID-19 pneumonia. Cardiac biomarkers increase was associated with both patients' preexisting conditions and markers of COVID-19 disease severity, as well as worse in-hospital outcome. Moreover, we described significant independent correlations between hs-Troponin and $\mathrm{PaO} 2 / \mathrm{FIO} 2$ and D-dimer on one side and between NP and history of CVD on the other. Increasing age remained an independent determinant of both cardiac biomarkers increase.

\section{Incidence}

In our analysis, more than one-third of patients had increased hs-Troponin level, though an elevation that exceeded more than three times the URN was observed only in $16 \%$ of the population, while NP elevation beyond URN was present in more than a half of our sample. Though multiple studies described lower incidence of myocardial injury in patients with COVID-19 pneumonia [6, 24], our findings are in keeping with what observed by others [12,25], likely in relation to older age and higher prevalence of comorbidities in these cohorts. Results from our population could be related to the peculiar epidemiology of COVID-19 pneumonia in Lazio region during the index period, which was in several cases related to clusters within nursing homes and rehabilitation clinics (partial nationwide data available at [26]). This highlights the heterogeneity of COVID-19 populations described by different studies, which in turn might explain existing differences in terms of patients' characteristics and outcomes $[6,12]$.

\section{Potential mechanisms underlying myocardial involvement}

We observed hs-Troponin and NP to be associated with both preexisting factors leading to higher vulnerability of myocardium (age, anemia, renal failure, previous CVD) as well as markers of COVID-19 pneumonia disease severity (D-dimer [9], CRP [24] and $\mathrm{PaO} 2 / \mathrm{FIO} 2$ [27]). This result reiterates the view of myocardial injury in the course of COVID-19 pneumonia as mainly caused by virus independent factors, including higher myocardial oxygen consumption, increased inflammatory driver and hypoxemia and favored by underlying comorbidities such as heart 
1472

Internal and Emergency Medicine (2020) 15:1467-1476
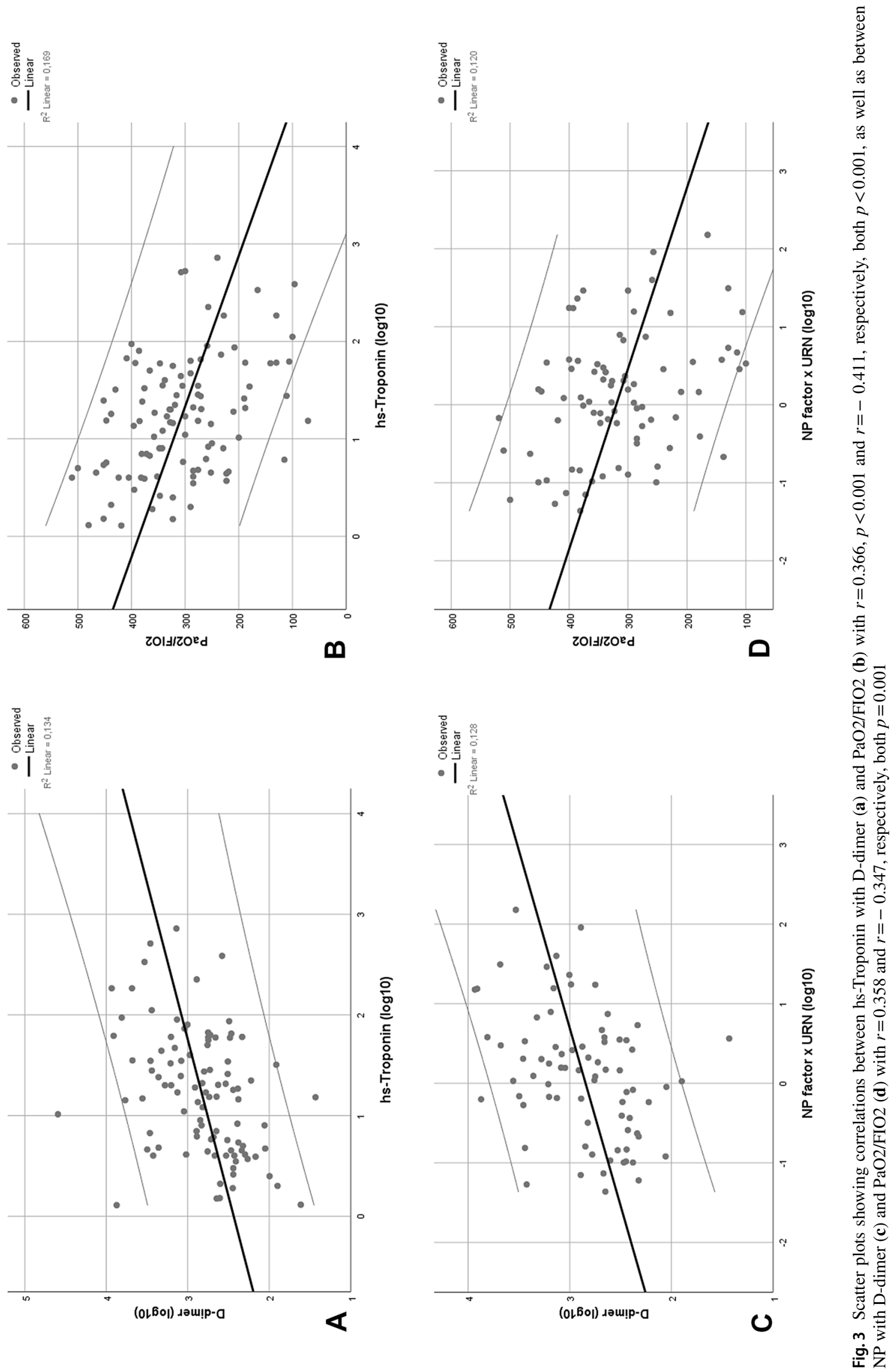

Springer 
Table 3 Multivariable linear regression of predictive associations with hs-Troponin and NP

\begin{tabular}{|c|c|c|c|c|c|c|c|}
\hline \multicolumn{4}{|c|}{ Hs-Troponin $(\log 10)$} & \multicolumn{4}{|c|}{ NP $(\log 10($ factor $\times$ URN $))$} \\
\hline Adj-R2 & Variable & Beta & $P$ & Adj-R2 & Variable & Beta & $P$ \\
\hline \multirow[t]{3}{*}{0.335} & Age & 0.419 & 0.001 & 0.442 & Age & 0.480 & $<0.001$ \\
\hline & $\mathrm{PaO} 2 / \mathrm{FIO} 2$ & -0.212 & 0.013 & & Previous CVD & 0.253 & 0.001 \\
\hline & D-dimer $(\log 10)$ & 0.179 & $\mathbf{0 . 0 3 7}$ & & & & \\
\hline
\end{tabular}

Independent variables included in both models: age, hemoglobin, creatinine, history of previous CVD, $\mathrm{PaO} 2 / \mathrm{FIO} 2$ and CRP and D-dimer. Bold values indicates $p<0.05$

$N P$ Natriuretic peptide, $C V D$ cardiovascular disease, $H b$ hemoglobin, $C R P$ C-reactive protein failure [18]. Of note, in the course of COVID-19 pneumonia [13, 16, 17], these factors have been described as potential drivers of both hs-Troponin and NP increase, which, as expected, had parallel trend in our population.

Notwithstanding, results from our study might point toward some existing differences in mechanisms leading to hs-Troponin and NP elevation in COVID-19 pneumonia. Indeed, we observed an independent association between both D-dimer and $\mathrm{PaO} 2 / \mathrm{FIO} 2$ with hs-Troponin, but not with NP. Interestingly, significantly elevated D-dimer concentration has been reported in COVID-19 patients with myocardial injury [10], but not in those with preexisting CVD [12]. Conversely, history of previous CVD was independently associated only with NP increase in our cohort, suggesting that preexisting underlying conditions such as heart failure and atrial fibrillation might be the major determinants of NP rather than hs-Troponin increase in these patients.

Reasons for reported findings cannot be discerned from data from our study as correlations we observed do not promptly imply the existence of any causative link. However, several hypotheses could be made to explain our observations. $\mathrm{PaO} 2 / \mathrm{FIO} 2$ ratio is a key parameter for defining acute respiratory distress syndrome [28] and in patients with COVID-19 pneumonia has been used as marker of disease severity [27] as well as end point in studies testing novel treatments [29]. Additionally, $\mathrm{PaO} 2 /$ FIO2 may decrease with higher oxygen consumption and lower cardiac output [30]: both elements can contribute to myocardial injury. High D-dimer is commonly found in patients with COVID-19 pneumonia [7], albeit not necessarily representing the occurrence of pulmonary embolism but inflammation, hypoxia and disseminated intravascular coagulation [9, 31], factors that can be all related to myocardial injury [11]. Furthermore, thrombosis of small vessels within lung and kidney has been reported by multiple studies (reviewed in [32, 33]), possibly favored by coexistent endotheliitis found in several organs, including the heart [34]. In this context, microvascular thrombosis in coronary vessels $[35,36]$ is an adjunctive potential mechanism consistent with our results, already anecdotally reported [37].

\section{Clinical implications}

Our findings could potentially carry clinical implications. The therapeutic management of COVID-19 pneumonia is currently based on supportive therapy and experimental approaches $[38,39]$. To provide a reliable discrimination of phenotypes within COVID-19 population could be helpful in order to plan targeted treatment [40], as hypothesized for patients with marked D-dimer elevation who might require higher anticoagulant dosage administration [41]. Based on our results, it is tempting to speculate whether increase of hs-Troponin might help identifying the subset of patients with higher systemic inflammatory response to COVID-19 infection, whereas NP the subgroup those in which preexisting CVD contributes more to the severe clinical course [12]. Finally, irrespective of the underlying mechanisms and in accordance with previous studies [10,13], we observed higher in-hospital mortality in patients with either high hsTroponin or NP within our population, strengthening the hypothesis that cardiac biomarkers assessment might provide useful information to aid COVID-19 pneumonia risk stratification.

\section{Limitations}

The present study should be read in light of several limitations. Though presenting a timely report regarding an ongoing medical emergency, the sample size is small, and results should be interpreted as hypothesis generating only, in need of further studies to ascertain the existence of any cause-effect relationship regarding the observed associations. Enrollment took place including patients consecutively admitted to medical units dedicated to COVID-19 assistance. However, it cannot be excluded that patients (especially males [42]) who were more severely affected when presenting to the emergency department were sent directly to intensive care units, thus being missed in our analysis. Due to safety reasons, and according to current specific guidelines [20], transthoracic echocardiography was performed only in a subset of patients within the whole population; hence, we could not provide comprehensive data 
regarding echocardiographic findings; notwithstanding, our results are in line with previous research linking right ventricular dysfunction to increased levels of cardiac biomarkers in COVID-19 pneumonia [43]. Individuals affected by COVID-19 represent a heterogeneous group of patients, in which the time and location of data collection may lead to significant variation among different samples; hence, our results cannot be immediately translated to study populations characterized by largely different demographic and clinical characteristics.

\section{Conclusions}

Cardiac biomarkers elevation was common in our cohort of patients with COVID-19 pneumonia and associated with worse prognosis. Independent association of hs-Troponin with $\mathrm{PaO} 2 / \mathrm{FIO} 2$ and D-dimer on one side, and of NP with history of CVD on the other, would require further studies to fully assess whether these biomarkers could effectively contribute to a reliable differentiation of phenotypes and subsequent treatment guidance in COVID-19 pneumonia patients.

Data availability Data will be made available upon request.

\section{Compliance with ethical standards}

Conflicts of interest The authors declare that they have no conflict of interest.

Ethics approval This study received the approval from Sapienza University Ethic Committee no. CE_5773_2020.

Consent to participate All patients provided informed consent for the use of their record for research purpose.

Consent for publication All authors have participated in the work and have reviewed and agree with article contents.

\section{References}

1. Zhu N, Zhang D, Wang W, Li X, Yang B, Song J, Zhao X, Huang B, Shi W, Lu R, Niu P, Zhan F, Ma X, Wang D, Xu W, Wu G, Gao GF, Tan W (2020) A novel coronavirus from patients with pneumonia in China, 2019. N Engl J Med 382:727-733. https:// doi.org/10.1056/NEJMoa2001017

2. Pennica A, Conforti G, Falangone F, Martocchia A, Tafaro L, Sentimentale A, Marini V, Pezzuto A, Spuntarelli V, Martelletti $P$ (2020) Clinical management of adult coronavirus infection disease 2019 (COVID-19) positive in the setting of low and medium intensity of care: a short practical review. SN Compr Clin Med. https://doi.org/10.1007/s42399-020-00333-w

3. Baraboutis IG, Gargalianos P, Aggelonidou E, Adraktas A (2020) Initial real-life experience from a designated COVID-19 centre in Athens, Greece: a proposed therapeutic algorithm. SN Compr Clin Med. https://doi.org/10.1007/s42399-020-00324-x
4. Cogliati C, Ceriani E, Brambilla AM (2020) When internal and emergency medicine speak to each other: organization in the time of COVID. Intern Emerg Med 15:891-892

5. Li Q, Guan X, Wu P, Wang X, Zhou L, Tong Y, Ren R, Leung KSM, Lau EHY, Wong JY, Xing X, Xiang N, Wu Y, Li C, Chen Q, Li D, Liu T, Zhao J, Liu M, Tu W, Chen C, Jin L, Yang R, Wang Q, Zhou S, Wang R, Liu H, Luo Y, Liu Y, Shao G, Li H, Tao Z, Yang Y, Deng Z, Liu B, Ma Z, Zhang Y, Shi G, Lam TTY, Wu JT, Gao GF, Cowling BJ, Yang B, Leung GM, Feng Z (2020) Early transmission dynamics in Wuhan, China, of novel coronavirus-infected pneumonia. N Engl J Med 382:1199-1207. https://doi.org/10.1056/NEJMoa2001316

6. Huang C, Wang Y, Li X, Ren L, Zhao J, Hu Y, Zhang L, Fan G, Xu J, Gu X, Cheng Z, Yu T, Xia J, Wei Y, Wu W, Xie X, Yin W, Li H, Liu M, Xiao Y, Gao H, Guo L, Xie J, Wang G, Jiang R, Gao Z, Jin Q, Wang J, Cao B (2020) Clinical features of patients infected with 2019 novel coronavirus in Wuhan, China. Lancet 395:497-506. https://doi.org/10.1016/S0140-6736(20)30183-5

7. Fogarty H, Townsend L, Ni Cheallaigh C, Bergin C, MartinLoeches I, Browne P, Bacon CL, Gaule R, Gillett A, Byrne M, Ryan K, O'Connell N, O'Sullivan JM, Conlon N, O'Donnell JS (2020) COVID19 coagulopathy in Caucasian patients. Br J Haematol. https://doi.org/10.1111/bjh.16749

8. Landi A, De Servi S (2020) The burden of thrombotic complications in critically ill patients with COVID-19: charting the uncharted. Intern Emerg Med 15:893-895

9. Zhang L, Yan X, Fan Q, Liu H, Liu X, Liu Z, Zhang Z (2020) $D$-dimer levels on admission to predict in-hospital mortality in patients with Covid-19. J Thromb Haemost. https://doi. org/10.1111/jth.14859

10. Guo T, Fan Y, Chen M, Wu X, Zhang L, He T, Wang H, Wan J, Wang X, Lu Z (2020) Cardiovascular implications of fatal outcomes of patients with coronavirus disease 2019 (COVID-19). JAMA Cardiol. https://doi.org/10.1001/jamacardio.2020.1017

11. Shi S, Qin M, Shen B, Cai Y, Liu T, Yang F, Gong W, Liu X, Liang J, Zhao Q, Huang H, Yang B, Huang C (2020) Association of cardiac injury with mortality in hospitalized patients with COVID-19 in Wuhan, China. JAMA Cardiol. https://doi. org/10.1001/jamacardio.2020.0950

12. Inciardi RM, Adamo M, Lupi L, Cani DS, Di Pasquale M, Tomasoni D, Italia L, Zaccone G, Tedino C, Fabbricatore D, Curnis A, Faggiano P, Gorga E, Lombardi CM, Milesi G, Vizzardi E, Volpini M, Nodari S, Specchia C, Maroldi R, Bezzi M, Metra M (2020) Characteristics and outcomes of patients hospitalized for COVID-19 and cardiac disease in Northern Italy. Eur Heart J. 41(19):1821-1829. https://doi.org/10.1093/eurhe artj/ehaa388

13. Gao L, Jiang D, Wen XS, Cheng XC, Sun M, He B, You LN, Lei P, Tan XW, Qin S, Cai GQ, Zhang DY (2020) Prognostic value of NT-proBNP in patients with severe COVID-19. Respir Res. https ://doi.org/10.1186/s12931-020-01352-w

14. Rath D, Petersen-Uribe Á, Avdiu A, Witzel K, Jaeger P, Zdanyte M, Heinzmann D, Tavlaki E, Müller K, Gawaz MP (2020) Impaired cardiac function is associated with mortality in patients with acute COVID-19 infection. Clin Res Cardiol. https://doi. org/10.1007/s00392-020-01683-0

15. Karbalai Saleh S, Oraii A, Soleimani A, Hadadi A, Shajari Z, Montazeri M, Moradi H, Talebpour M, Sadat Naseri A, Balali P, Akhbari M, Ashraf H (2020) The association between cardiac injury and outcomes in hospitalized patients with COVID-19. Intern Emerg Med. https://doi.org/10.1007/s11739-020-02466-1

16. Libby $\mathrm{P}$ (2020) The heart in COVID19: primary target or secondary bystander? JACC Basic to Transl Sci. https://doi. org/10.1016/j.jacbts.2020.04.001

17. Tersalvi G, Vicenzi M, Calabretta D, Biasco L, Pedrazzini G, Winterton D (2020) Elevated troponin in patients with Coronavirus 
Disease 2019 (COVID-19): possible mechanisms. J Card Fail. https://doi.org/10.1016/j.cardfail.2020.04.009

18. Tomasoni D, Italia L, Adamo M, Inciardi RM, Lombardi CM, Solomon SD, Metra M (2020) <scp >COVID </scp $>19$ and heart failure: from infection to inflammation and angiotensin $<$ scp $>$ II $<$ I scp $>$ stimulation. Searching for evidence from a new disease. Eur J Heart Fail. https://doi.org/10.1002/ejhf.1871

19. Puntmann VO, Carerj ML, Wieters I, Fahim M, Arendt C, Hoffmann J, Shchendrygina A, Escher F, Vasa-Nicotera M, Zeiher AM, Vehreschild M, Nagel E (2020) Outcomes of cardiovascular magnetic resonance imaging in patients recently recovered from coronavirus disease 2019 (COVID-19). JAMA Cardiol. https:// doi.org/10.1001/jamacardio.2020.3557

20. Skulstad H, Cosyns B, Popescu BA, Galderisi M, Di Salvo G, Donal E, Petersen S, Gimelli A, Haugaa KH, Muraru D, Almeida AG, Schulz-Menger J, Dweck MR, Pontone G, Sade LE, Gerber B, Maurovich-Horvat P, Bharucha T, Cameli M, Magne J, Westwood M, Maurer G, Edvardsen T (2020) COVID-19 pandemic and cardiac imaging: EACVI recommendations on precautions, indications, prioritization, and protection for patients and healthcare personnel. Eur Heart J Cardiovasc Imaging. 21(6):592-598. https://doi.org/10.1093/ehjci/jeaa072

21. Favaloro E, Thachil J (2020) Reporting of D-dimer data in COVID-19: some confusion and potential for misinformation. Clin Chem Lab Med. https://doi.org/10.1515/CCLM-2020-0573

22. Ponikowski P, Voors AA, Anker SD, Bueno H, Cleland JGF, Coats AJS, Falk V, González-Juanatey JR, Harjola V-P, Jankowska EA, Jessup M, Linde C, Nihoyannopoulos P, Parissis JT, Pieske B, Riley JP, Rosano GMC, Ruilope LM, Ruschitzka F, Rutten FH, van der Meer P, ESC Scientific Document Group (2016) 2016 ESC Guidelines for the diagnosis and treatment of acute and chronic heart failure. Eur Heart J 37:2129-2200. https://doi. org/10.1093/eurheartj/ehw128

23. Blackshear JL, Safford RE, Thomas CS, Bos JM, Ackerman MJ, Geske JB, Ommen SR, Shapiro BP, Johns GS (2018) Platelet function analyzer 100 and brain natriuretic peptide as biomarkers in obstructive hypertrophic cardiomyopathy. Am J Cardiol 121:768-774. https://doi.org/10.1016/j.amjcard.2017.12.009

24. Liu F, Li L, Da XuM, Wu J, Luo D, Zhu YS, Li BX, Song XY, Zhou X (2020) Prognostic value of interleukin-6, C-reactive protein, and procalcitonin in patients with COVID-19. J Clin Virol 127:104370. https://doi.org/10.1016/j.jcv.2020.104370

25. Deng Q, Hu B, Zhang Y, Wang H, Zhou X, Hu W, Cheng Y, Yan J, Ping H, Zhou Q (2020) Suspected myocardial injury in patients with COVID-19: evidence from front-line clinical observation in Wuhan, China. Int J Cardiol. https://doi.org/10.1016/j.ijcar d.2020.03.087

26. https://www.epicentro.iss.it/coronavirus/bollettino/Bollettino -sorveglianza-integrata-COVID-19_7-maggio-2020.pdf (last accessed on June $1^{\text {st }} 2020$ ).

27. Wang Y, Zhang D, Du G, Du R, Zhao J, Jin Y, Fu S, Gao L, Cheng Z, Lu Q, Hu Y, Luo G, Wang K, Lu Y, Li H, Wang S, Ruan S, Yang C, Mei C, Wang Y, Ding D, Wu F, Tang X, Ye X, Ye Y, Liu B, Yang J, Yin W, Wang A, Fan G, Zhou F, Liu Z, Gu X, Xu J, Shang L, Zhang Y, Cao L, Guo T, Wan Y, Qin H, Jiang Y, Jaki T, Hayden FG, Horby PW, Cao B, Wang C (2020) Remdesivir in adults with severe COVID-19: a randomised, double-blind, placebo-controlled, multicentre trial. Lancet 395:1569-1578. https ://doi.org/10.1016/S0140-6736(20)31022-9

28. Ranieri VM, Rubenfeld GD, Thompson BT, Ferguson ND, Caldwell E, Fan E, Camporota L, Slutsky AS (2012) Acute respiratory distress syndrome: the Berlin definition. JAMA 307:2526-2533. https://doi.org/10.1001/jama.2012.5669

29. Christie DB, Nemec HM, Scott AM, Buchanan JT, Franklin CM, Ahmed A, Khan MS, Callender CW, James EA, Christie AB, Ashley DW (2020) Early outcomes with utilization of tissue plasminogen activator in COVID-19 associated respiratory distress: a series of five cases. J Trauma Acute Care Surg. https:// doi.org/10.1097/TA.0000000000002787

30. Gattinoni L, Vassalli F, Romitti F (2018) Benefits and risks of the $\mathrm{P} / \mathrm{F}$ approach. Intensive Care Med 44:2245-2247

31. Leonard-Lorant I, Delabranche X, Severac F, Helms J, Pauzet C, Collange O, Schneider F, Labani A, Bilbault P, Moliere S, Leyendecker P, Roy C, Ohana M (2020) Acute pulmonary embolism in COVID-19 patients on CT angiography and relationship to D-Dimer levels. Radiology. https://doi.org/10.1148/radiol.20202 01561

32. Kang Y, Chen T, Mui D, Ferrari V, Jagasia D, Scherrer-Crosbie M, Chen Y, Han Y (2020) Cardiovascular manifestations and treatment considerations in covid-19. Heart. https://doi.org/10.1136/ heartjnl-2020-317056

33. Coccheri S (2020) COVID-19: the crucial role of blood coagulation and fibrinolysis. Intern Emerg Med. https://doi.org/10.1007/ s11739-020-02443-8

34. Varga Z, Flammer AJ, Steiger P, Haberecker M, Andermatt R, Zinkernagel AS, Mehra MR, Schuepbach RA, Ruschitzka F, Moch $\mathrm{H}$ (2020) Endothelial cell infection and endotheliitis in COVID19. Lancet 395:1417-1418

35. Boral BM, Williams DJ, Boral LI (2016) Disseminated intravascular coagulation. Am J Clin Pathol 146:670-680. https://doi. org/10.1093/ajcp/aqw195

36. Hendren NS, Drazner MH, Bozkurt B, Cooper LT Jr (2020) Description and Proposed Management of the Acute COVID-19 Cardiovascular Syndrome. Circulation. 141(23):1903-1914. https ://doi.org/10.1161/CIRCULATIONAHA.120.047349

37. Hanley B, Naresh KN, Roufosse C, Nicholson AG, Weir J, Cooke GS, Thursz M, Manousou P, Corbett R, Goldin R, Al-Sarraj S, Abdolrasouli A, Swann OC, Baillon L, Penn R, Barclay WS, Viola P, Osborn M (2020) Histopathological findings and viral tropism in UK patients with severe fatal COVID-19: a post-mortem study. Lancet Microbe. https://doi.org/10.1016/S2666-5247(20)30115-4

38. Grein J, Ohmagari N, Shin D, Diaz G, Asperges E, Castagna A, Feldt T, Green G, Green ML, Lescure F-X, Nicastri E, Oda R, Yo K, Quiros-Roldan E, Studemeister A, Redinski J, Ahmed S, Bernett J, Chelliah D, Chen D, Chihara S, Cohen SH, Cunningham J, D'Arminio Monforte A, Ismail S, Kato H, Lapadula G, L'Her E, Maeno T, Majumder S, Massari M, Mora-Rillo M, Mutoh Y, Nguyen D, Verweij E, Zoufaly A, Osinusi AO, DeZure A, Zhao Y, Zhong L, Chokkalingam A, Elboudwarej E, Telep L, Timbs L, Henne I, Sellers S, Cao H, Tan SK, Winterbourne L, Desai P, Mera R, Gaggar A, Myers RP, Brainard DM, Childs R, Flanigan T (2020) Compassionate use of Remdesivir for patients with severe Covid-19. N Engl J Med. https://doi.org/10.1056/nejmoa2007016

39. Panati K, Narala VR (2020) COVID-19 outbreak: an update on therapeutic options. SN Compr Clin Med 2:379-380. https://doi. org/10.1007/s42399-020-00264-6

40. Gattinoni L, Chiumello D, Caironi P, Busana M, Romitti F, Brazzi L, Camporota L (2020) COVID-19 pneumonia: different respiratory treatment for different phenotypes? Intensive Care Med. https://doi.org/10.1007/s00134-020-06033-2

41. Tang N, Bai H, Chen X, Gong J, Li D, Sun Z (2020) Anticoagulant treatment is associated with decreased mortality in severe coronavirus disease 2019 patients with coagulopathy. J Thromb Haemost 18:1094-1099. https://doi.org/10.1111/jth.14817

42. Kim L, Garg S, O'Halloran A, Whitaker M, Pham H, Anderson EJ, Armistead I, Bennett NM, Billing L, Como-Sabetti K, Hill M, Kim S, Monroe ML, Muse A, Reingold AL, Schaffner W, Sutton M, Talbot HK, Torres SM, Yousey-Hindes K, Holstein R, Cummings C, Brammer L, Hall AJ, Fry AM, Langley GE (2020) Risk factors for intensive care unit admission and in-hospital mortality among hospitalized adults identified through the U.S. coronavirus disease 2019 (COVID-19)-associated hospitalization surveillance 
network (COVID-NET). Clin Infect Dis. https://doi.org/10.1093/ cid/ciaa1012

43. Szekely Y, Lichter Y, Taieb P, Banai A, Hochstadt A, Merdler I, Gal Oz A, Rothschild E, Baruch G, Peri Y, Arbel Y, Topilsky $Y$ (2020) The spectrum of cardiac manifestations in coronavirus disease 2019 (COVID-19) — a systematic echocardiographic study. Circulation. https://doi.org/10.1161/CIRCULATIO NAHA.120.047971
Publisher's Note Springer Nature remains neutral with regard to jurisdictional claims in published maps and institutional affiliations.

\section{Affiliations}

\section{Luca Arcari $^{1,2}$ (D) Michelangelo Luciani ${ }^{3} \cdot$ Luca Cacciotti $^{1,2} \cdot$ Maria Beatrice Musumeci $^{4,5} \cdot$ Valerio Spuntarelli $^{3,6}$. Eleonora Pistella ${ }^{2,7} \cdot$ Dario Martolini ${ }^{2,7} \cdot$ Daniele Manzo $^{1,2} \cdot$ Mariateresa Pucci $^{2} \cdot$ Claudio Marone $^{2,7}$. Serena Melandri, ${ }^{2,7} \cdot$ Gerardo Ansalone $^{1} \cdot$ Claudio Santini $^{2,7} \cdot$ Paolo Martelletti ${ }^{3,6} \cdot$ Massimo Volpe $^{4,8}$. Luciano De Biase B,9 $^{5,9}$}

1 Department of Cardiology, Madre Giuseppina Vannini Hospital, Via di Acqua Bullicante 4, 00177 Rome, Italy

2 Covid Unit 2, Madre Giuseppina Vannini Hospital, Rome, Italy

3 Internal Medicine Unit, Clinical and Molecular Medicine Department, Faculty of Medicine and Psychology, Sapienza University of Rome, Rome, Italy

4 Clinical and Molecular Medicine Department, Faculty of Medicine and Psychology, Cardiology Unit, Sapienza University of Rome, Rome, Italy

5 Heart Failure Unit, Clinical and Molecular Medicine Department, Faculty of Medicine and Psychology, Covid Unit, Sapienza University of Rome, Rome, Italy
6 Emergency Medicine, Department of Clinical and Molecular Medicine, Covid Unit, Sapienza University, Sant'Andrea Hospital, Rome, Italy

7 Internal Medicine Department, Madre Giuseppina Vannini Hospital, Rome, Italy

8 IRCCS Neuromed, Pozzilli, Isernia, Italy

9 Heart Failure Unit, Clinical and Molecular Medicine Department, Faculty of Medicine and Psychology, Sapienza University of Rome, Rome, Italy 